\title{
A study of serum zinc, albumin, alpha-2-macroglobulin and transferrin levels in acute and long stay elderly hospital patients
}

\author{
G.M. Craig, S.J. Evans, B.J. Brayshaw and S.K. Raina \\ Departments of Geriatric Medicine and Clinical Biochemistry, General Hospital, Northampton NNI 5BD, \\ $U K$.
}

\begin{abstract}
Summary: Serum zinc levels measured by atomic absorption spectrophotometry were found to be low (less than $10.5 \mu \mathrm{mol} / \mathrm{l}$ ) in $38 \%$ of acute geriatric admissions, $69 \%$ of long stay geriatric patients and $19 \%$ of a control group of elderly hospital patients with a normal serum albumin.

There was a significant positive correlation between serum zinc and serum albumin in all groups. In acutely ill geriatric patients only, there was a weak but statistically significant positive correlation between serum zinc and alpha-2-macroglobulin (A2M) $(r=0.20), P<0.05)$.

Serum transferrin was low in $46 \%$ of acute geriatric patients and $22 \%$ of long stay geriatric patients but there was no correlation between serum zinc and serum transferrin levels in any patient group. There were significant differences in serum zinc, A2M and transferrin levels between the acute and long stay geriatric patients. The differences in serum zinc levels between these patient groups could not be explained by changes in serum A2M, transferrin or albumin. Changes mediated by an acute phase response may have influenced results in the acute geriatric group of patients.
\end{abstract}

\section{Introduction}

Nutritional zinc deficiency is widespread particularly amongst third world populations living primarily on cereal proteins. ${ }^{1}$ However, even in developed nations the elderly, especially those in institutions, are at risk. A small nutritional survey in Australia showed that $21 \%$ of community based elderly and $85 \%$ of institutionalized elderly ate less than two thirds of the recommended daily zinc intake of $15 \mathrm{mg} .^{2}$ The average daily dietary intake of zinc in elderly persons in the USA is also reported to be low, ranging from 7 to $13 \mathrm{mg}^{3}$ It has been reported that elderly long stay patients have lower serum zinc and leucocyte zinc levels than the elderly living in the community, but the difference cannot be explained on the basis of diet alone. ${ }^{4}$

Thus, although dietary deficiency can cause zinc deficiency in the elderly, other factors should be considered. ${ }^{5}$ Increased zinc loss occurs with diuretic therapy, in uraemia and alcoholism and in patients with extensive burns. Malabsorption of zinc occurs in Crohn's disease and inflammatory

Correspondence: G.M. Craig, M.D., M.R.C.P., Department of Geriatric Medicine, St Edmund's Hospital, Northampton NN1 4DS, UK.

Accepted: 5 October 1989 bowel disease. Zinc deficiency can be secondary to non-insulin-dependent diabetes mellitus or total parenteral nutrition.

Acute influx of zinc into the liver occurs in response to tissue injury ${ }^{6}$ and bacterial infection ${ }^{7}$ through the action of factors such as interleukin I, a chemical mediator released from activated macrophages. ${ }^{8}$ This hepatic uptake of zinc is associated with synthesis of alpha-2-acute phase reactant proteins. ${ }^{9,10}$

Changes in serum zinc can be secondary to changes in zinc binding proteins, since $98 \%$ of serum zinc is protein bound and less than $2 \%$ is free. In human serum, zinc is bound primarily to albumin $(80-85 \%)$ but $5-15 \%$ is bound to $\alpha_{2}$ macroglobulin (A2M). ${ }^{11,12}$ A small fraction of circulating zinc is bound to retinol binding protein and amino acids. Zinc binding to transferrin is probably insignificant. ${ }^{13}$

In summary, a low plasma or serum zinc may indicate depletion of stores in response to inadequate intake or excess loss, enhanced hepatic uptake of zinc in response to tissue injury and infection, or low levels of zinc binding protein.

The present study was undertaken to investigate and compare the incidence of zinc deficiency, as judged by a low serum zinc level, in acute geriatric 
admissions and long stay geriatric patients. Although leucocyte zinc may be a better indicator of tissue stores than is the serum or plasma zinc, leucocyte zinc assays are not widely available. Serum zinc gives a useful indication of zinc status when considered in conjunction with clinical features of the case. ${ }^{14}$

In addition to serum zinc we measured the zinc binding proteins albumin and A2M. Serum transferrin was measured and a routine biochemical profile was obtained from every patient.

\section{Patients and methods}

The study was undertaken in three separate groups of elderly patients using a protocol approved by the local Research and Ethics Committee. The patient groups were as follows:-

Acute geriatric group The acute geriatric patients were 107 consecutive acute admissions to geriatric wards from November 1985 and comprised 46 males, mean age 82.2 years (range 68 to 97 years) and 61 females, mean age 82.6 years (range 68 to 97). All blood samples were taken after breakfast during the first week of admission and in most cases within one or two days of admission.

Long stay geriatric group A group of 51 long stay geriatric patients were selected with a variety of pathology, particularly cerebrovascular disease, arthritis and senile dementia. Each patient had been in hospital for at least three months. The group comprised 26 males with a mean age of 77.6 years (range 61 to 92 years) and 25 females with a mean age of 85.9 years (range 67 to 100).

Normal albumin control group This group consisted of 102 elderly patients from general medical or surgical wards and out-patient clinics who had normal serum levels of total protein and albumin.
All had normal serum bilirubin and aspartate aminotransferase levels, and the majority (74\%) had normal renal function. There were 37 males with a mean age of 72.3 years (range 65 to 85 ) and 65 females with a mean age of 76.0 years (range 65 to 92 ).

Blood samples were collected from each patient for routine biochemical profile, serum zinc, transferrin and $\mathrm{A} 2 \mathrm{M}$ determinations. The biochemical profiles were undertaken on a Technicon SMA II autoanalyser using standard methodologies. Serum zinc was measured by atomic absorption spectrophotometry. Samples for transferrin and A2M estimations were stored frozen at $-20^{\circ} \mathrm{C}$ and were assayed using standard Mancini end point radial immunodiffusion techniques on commercial plates. The between batch imprecision of these methods measured as coefficients of variations were transferrin $6.7 \%$ (at $3.7 \mathrm{~g} / \mathrm{l}$ ) and A2M $5.0 \%$ (at $2.2 \mathrm{~g} / 1$ ).

The data presented were analysed using Student's $t$-test and linear regression was calculated by the least squares method. A $P$ value of less than 0.05 was considered statistically significant.

\section{Results}

The biochemical data for each of the three patient groups are summarised in Table I. The serum zinc concentrations in the acute geriatric and long stay geriatric patients were significantly lower than those of the control group $(P<0.001$ in each instance). Serum zinc results in the long stay group were significantly lower than those in the acute group $(P<0.01)$.

Altogether, $38 \%$ of the acute geriatric group, $69 \%$ of the long stay geriatric group and $19 \%$ of the normal albumin control group had serum zinc levels below the bottom of the locally used reference range for healthy adults in the 25 to 50

Table I Serum biochemical results (mean \pm s.d.) with statistical comparisons

\begin{tabular}{|c|c|c|c|c|c|c|c|}
\hline \multirow{2}{*}{$\begin{array}{l}\text { Biochemical } \\
\text { parameter } \\
\text { measured }\end{array}$} & \multirow[b]{2}{*}{$\begin{array}{l}\text { Reference } \\
\text { range }\end{array}$} & \multirow{2}{*}{$\begin{array}{c}\text { Acute } \\
\text { geriatric } \\
\text { group } \\
(n=107)\end{array}$} & \multirow{2}{*}{$\begin{array}{l}\text { Long stay } \\
\text { geriatric } \\
\text { group } \\
(n=51)\end{array}$} & \multirow{2}{*}{$\begin{array}{l}\text { Normal } \\
\text { albumin } \\
\text { control } \\
\text { group } \\
(n=102)\end{array}$} & \multicolumn{3}{|c|}{$\begin{array}{l}\text { Statistical comparison between } \\
\text { groups }(P)\end{array}$} \\
\hline & & & & & $\begin{array}{l}\text { Acute/long } \\
\text { stay }\end{array}$ & $\begin{array}{l}\text { Acute/ } \\
\text { control }\end{array}$ & $\begin{array}{l}\text { Long } \\
\text { stay/control }\end{array}$ \\
\hline Zinc & $10.5-18.5 \mu \mathrm{mol} / \mathrm{l}$ & $10.72 \pm 2.83$ & $9.43 \pm 1.93$ & $12.71 \pm 2.45$ & $<0.01$ & $<0.001$ & $<0.001$ \\
\hline Total protein & $60-80 \mathrm{~g} / 1$ & $66.3 \pm 7.7$ & $67.0 \pm 4.8$ & $70.1 \pm 4.8$ & NS & $<0.001$ & $<0.001$ \\
\hline Albumin & $35-50 \mathrm{~g} / 1$ & $36.0 \pm 5.1$ & $36.7 \pm 3.0$ & $41.3 \pm 3.0$ & NS & $<0.001$ & $<0.001$ \\
\hline A2M & $1.3-3.8 \mathrm{~g} / 1$ & $2.75 \pm 0.57$ & $2.49 \pm 0.31$ & $2.67 \pm 0.57$ & $<0.01$ & NS & NS \\
\hline Transferrin & $2.0-4.0 \mathrm{~g} / 1$ & $2.07 \pm 0.73$ & $2.33 \pm 0.46$ & $2.70 \pm 0.64$ & $<0.02$ & $<0.001$ & $<0.001$ \\
\hline Urea & $3.3-6.7 \mathrm{mmol} / 1$ & $10.23 \pm 8.11$ & $7.13 \pm 2.96$ & $6.66 \pm 2.27$ & $<0.01$ & $<0.001$ & NS \\
\hline $\begin{array}{l}\text { Alkaline } \\
\text { phosphatase }\end{array}$ & $30-135 \mathrm{IU} / 1$ & $135 \pm 74$ & $119 \pm 54$ & $97 \pm 35$ & NS & $<0.001$ & $<0.01$ \\
\hline
\end{tabular}


age group.

Serum zinc levels in the long stay group were fairly normally distributed around a low mean; no patient in the group had a serum zinc above the mid point of the normal range.

There was a statistically significant positive correlation between the serum zinc and total protein in the normal albumin control group $(r=0.23, P<0.05)$ and in the acute geriatric group $(r=0.41, P<0.001)$. There was a significant positive correlation between the serum zinc and albumin levels in all three patient groups (Figure 1).

The serum transferrin levels in the acute geriatric and long stay geriatric groups were significantly lower than the levels in the normal albumin control group $(P<0.001$ in each instance). Transferrin levels in the acute geriatric group were significantly lower than levels in the long stay geriatric group $(P<0.02)$. There was no statistically significant correlation between the serum zinc and transferrin levels in any patient group. The mean A2M levels for each group fell within the reference range. The levels in the acute geriatric patients were significantly higher than those in the long stay geriatric group $(P<0.01)$. A weak but statistically significant positive correlation was found between serum zinc and $\mathbf{A} 2 \mathrm{M}$ in the acute geriatric group $(r=0.21, P<0.05)$.

\section{Discussion}

The local reference range for serum zinc (10.5 to $18.5 \mu \mathrm{mol} / \mathrm{l}$ ) is based on results in healthy young adults. It has been reported that serum zinc levels in young healthy controls and healthy elderly in the community do not differ. ${ }^{4,15}$ Stafford $e t$ al. ${ }^{4}$ quoted a mean serum zinc of $12.74 \mu \mathrm{mol} / 1$ in a control group of 26 elderly living in the community in Edinburgh. The mean serum zinc in our normal albumin control group was $12.71 \mu \mathrm{mol} / \mathrm{l}$. However, as our normal albumin control patients were all attending hospital, they cannot be regarded as an elderly reference population. The group is included for comparative purposes. Results indicate that $19 \%$ of elderly hospital patients with a normal serum albumin have a low serum zinc.

Our results demonstrate that a very high percentage of elderly patients on geriatric acute admission wards and long stay wards have a low serum zinc. Others have reported a low serum zinc in $29 \%$ of institutionalized elderly. ${ }^{2}$ Elderly long stay patients have been shown to have significantly lower serum zinc and leucocyte zinc levels than elderly people in the community ${ }^{4,15}$ but to date no one has compared serum zinc levels in acute and long stay elderly patients. Our observation that there are significant differences in serum zinc, transferrin and A2M
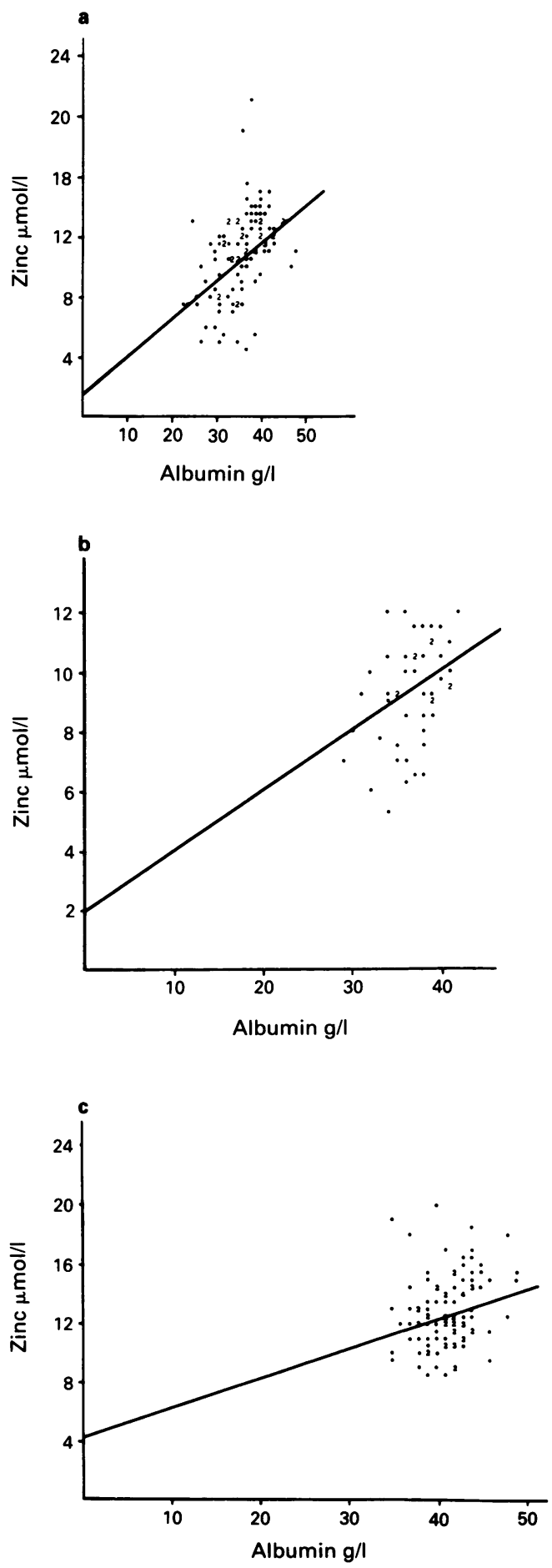

Figure 1 Correlation between serum zinc and albumin in each patient group. (a) Acute group $r=0.46 P<0.001$; (b) long stay group $r=0.32, P<0.05$; (c) normal albumin control group $r=0.25, P<0.02$. 
levels between geriatric acute admissions and long stay geriatric patients appears to be new.

Serum transferrin was measured primarily as an indicator of severe protein calorie malnutrition, ${ }^{16}$ since much attention has been devoted to dietary aspects of zinc deficiency in the elderly. However, as others have noted ${ }^{4}$ this is not the whole story. The highest incidence of zinc deficiency $(69 \%)$ as judged by a low serum zinc was found in the sample of long stay geriatric patients. All the long stay patients had been on a hospital diet for at least three months and in most cases considerably longer. However, more acute geriatric admissions than long stay patients had a low serum transferrin ( $46 \%$, compared with $22 \%$ ). Although there is good evidence that transferrin levels decline in severe protein calorie malnutrition (PCM), the use of transferrin in the diagnosis of moderate malnutrition is open to doubt. ${ }^{16}$ Even if all the long stay geriatric patients with a low transferrin were assumed to have severe protein-calorie malnutrition, only a third of their low zinc results could be explained on this basis. The possibility arises that a low serum zinc may contribute to the pathology that results in placement on a long stay ward.

The relationship between serum zinc and albumin levels is complex. Not only is albumin a major zinc carrier protein, but zinc deficiency may impair albumin synthesis in humans. ${ }^{17,18}$ Utilization of amino-acids for protein synthesis is impaired in zinc-deficient animals, ${ }^{19}$ and DNA synthesis is decreased. ${ }^{20}$ We found a significant positive correlation between serum zinc and serum albumin in all patient groups, which supports the findings of others. ${ }^{4,12}$ On the other hand, Australian workers found no relationship between serum zinc and serum albumin in the elderly, despite a significant $(P<0.001)$ positive correlation between serum albumin and zinc intake. ${ }^{2}$ We do not feel that the changes in serum zinc in our patients can be attributed solely to changes in serum albumin, since mean serum zinc levels were significantly different in the acute and long stay geriatric patients, in the absence of any significant difference in albumin levels between these two groups. Moreover, $19 \%$ of the normal albumin control group had a low serum zinc.

Alpha-2-macroglobulin is a glycoprotein that is synthesized by the liver, monocytes, lymphocytes, fibroblasts and alveolar macrophages. It is a major zinc binding protein to which zinc is tightly bound. ${ }^{11,12} \mathrm{~A} 2 \mathrm{M}$ is also a proteinase inhibitor that acts as a general scavenger of proteinases, both endogenous and arising from infective agents, thereby protecting blood and tissue proteins from damage. A2M traps and binds trypsin, chymotrypsin, plasmin, thrombin, pancreatic elastase and leucocyte elastase. Trypsin-A2M complexes appear to have some endocrine and metabolic func- tions. ${ }^{21}$ In general, A2M is thought to modulate various immune and inflammatory responses. It may stimulate the liver to synthesize acute phase reactants. Binding of plasmin and thrombin by A2M may help maintain haemostatic balance. A2M is bound to the surface of vascular endothelial cells and may have a protective role here. A2M binds certain nonproteinase proteins, such as insulin and growth hormone, but the physiological significance of this is unknown. ${ }^{21}$ Levels of A2M rise in the nephrotic syndrome and diabetes and fall in trauma, after fibrinolytic therapy ${ }^{21}$ and in necrotizing pancreatitis. ${ }^{22} \mathrm{~A} 2 \mathrm{M}$ - proteinase complexes are rapidly cleared from circulation by reticuloendothelial cells by a process of receptor-mediated endocytosis.

A2M is not usually considered to be an acutephase reactant in man, but in the rat following on inflammatory stimulation, A2M levels increase dramatically and acute phase control of its messenger RNA has been demonstrated. ${ }^{23}$ In view of this we anticipated that A2M levels might be increased in our acute group patients, many of whom were admitted with infections. In fact less than $4 \%$ of the patients had a raised A2M. Mean A2M levels were, however, significantly higher in the acute group than in the long stay group although the results for each group fell within the reference range. The weak but statistically significant positive correlation between $\mathrm{A} 2 \mathrm{M}$ and zinc in the acute group was interesting and has not been reported before. However, we were unable to confirm this observation in 135 acute geriatric patients studied in 1987. Others have found no definite correlation between serum zinc and A2M in a small number of patients with varied pathology. ${ }^{12,24}$

Changes mediated by an acute phase response may have influenced the serum zinc and transferrin results particularly in the acute group of patients. Measurement of interleukin I was beyond our resources but since $\mathrm{C}$-reactive protein (CRP) is a good indicator of an acute phase response ${ }^{25}$ we measured CRP retrospectively on stored sera. Approximately $62 \%(n=103)$ of the acute group of patients had CRP levels above $10 \mathrm{mg} / 1$, compared with $30 \%$ of the long stay group $(n=50)$ and $23 \%$ of the normal albumin control patients $(n=71)$. There was a significant negative correlation between zinc and CRP in the acute group only $(r=-0.33, P<0.001)$. These results will be reported fully in a separate paper.

\section{Acknowledgements}

We thank our Consultant colleagues, in particular Dr R. Sutcliffe and Dr B. Morgan, for allowing us to study patients under their care. Smith, Kline and French Laboratories kindly reimbursed the cost of some assays. 


\section{References}

1. Prasad, A.S. Discovery and importance of zinc in human nutrition. Fed Proc 1984, 43: 2829-2834.

2. Flint, D.M., Wahlqvist, M.L., Smith, T.J. \& Parish, A.E. Zinc and protein status in the elderly. J Human Nutr 1981, 35: 287-295.

3. Sandstead, H.H., Henriksen, L.K., Greger, J.L., Prasad, A.S. \& Good, R.A. Zinc nutriture in the elderly in relation to taste acuity, immune response and wound healing. Am J Clin Nutr 1982, 36: 1046-1059.

4. Stafford, W., Smith, R.G., Lewis, S.J. et al. A study of zinc status of elderly institutionalised patients. Age Ageing 1988, 17: 42-48.

5. Lindeman, R.D. \& Mills, B.J. Zinc homeostasis in health and disease. Miner Electrolyte Metab 1980. 3: 223-236.

6. Lindeman, R.D., Bottomley, R.G., Cornelison, R.L. \& Jacobs, L.A. Influence of acute tissue injury on zinc metabolism in man. $J$ Lab Clin Med 1972, 79: 452-460.

7. Beisel, W.R. Zinc metabolism in infection. In: Brewer, G.J. and Prasad, A.S. (eds) Zinc Metabolism. Current Aspects in Health and Disease. Liss, New York, 1977, pp. 155-176.

8. Dinarello, C.A. An update on human Interleukin I; from molecular biology to clinical relevance. Clin Immunol 1985, 5: 287-296.

9. Powanda, M.C. Changes in body balance of nitrogen and other key nutrients - description and underlying mechanisms. Am J Clin Nutr 1977, 30: 1254-1268.

10. Prasad, A.S. Clinical endocrinological and biochemical effects of zinc deficiency. Clin Endocrinol Metab 1985, 14: 567-589.

11. Foote, J.W. \& Delves, H.T. Albumin bound and alpha-2macroglobulin bound zinc concentrations in the sera of healthy adults. J Clin Pathol 1984, 37: 1050-1054.

12. Kiilerich, S. \& Christiansen, C. Distribution of serum zinc between albumin and alpha-2-macroglobulin in patients with different zinc metabolic disorders. Clin Chim Acta 1986, 154: $1-6$.

13. Chesters, J.K. \& Will, M. Zinc transport proteins in plasma. Br J Nutr 1981, 46: 111-118.

14. Jackson, M.J., Jones, D.A. \& Edwards, R.H.T. Tissue zinc levels as an index of body zinc status. Clin Physiol 1982, 2: $333-343$.
15. Senapati, A., Jenner, G.H. \& Thompson, R.P.H. Zinc in the elderly. $Q J$ Med 1989, 261: 81-87.

16. Haider, M. \& Haider, S.Q. Assessment of protein-calorie malnutrition. Clin Chem 1984, 30: 1286-1299.

17. Bates, J. \& McClain, C.J. The effect of severe zinc deficiency on serum levels of albumin, transferrin and prealbumin in man. Am J Clin Nutr 1981, 34: 1655-1660.

18. Wahlqvist, M.L., Flint, D.M., Prinsley, D.M. \& Dryden, P.A. The effect of zinc supplementation on serum albumin and folic acid concentrations in a group of hypoalbuminaemic and hypozincaemic aged persons. In: Howard, A.N. \& McLean Baird, I. (eds) Recent Advances in Clinical Nutrition, vol. 1. Libbey, London. 1981, pp. 83-84.

19. Hsu, J.M., Anthony, W.L. \& Buchanan, P.J. Zinc deficiency and incorporation of $14 \mathrm{C}$ - labelled methionine into tissue proteins in rats. $J$ Nutr 1969 , 99: 425-432.

20. Prasad, A.S., Oberleas, D. \& Koniuch, D. Thymidine kinase activity and incorporation of thymidine into DNA in zinc deficient tissue. J Lab Clin Med 1974, 83: 634-639.

21. Roberts, R.C. Proteinase inhibitors of human plasma. Alpha2-macroglobulin. J. Med 1985, 16: 129-224.

22. Buchler, M., Malfertheiner, P., Schoetensack, C., Uhl, W. \& Beger, H.G. Sensitivity of antiproteases, complement factors and C-reactive protein in detecting pancreatic necrosis. Results of a prospective clinical study. Int J Pancreatol 1986, 1: $227-235$.

23. Gehring, M.R., Shiels, B.R., Northemann, W. et al. Sequence of rat liver alpha-2-macroglobulin and acute phase control of its messenger RNA. J Biol Chem 1987, 262: 446-458.

24. McBean, L.D., Smith, J.C.Jr, Berne, B.H. \& Halstead, J.A. Serum zinc and alpha 2 macroglobulin concentration in myocardial infarction, decubitus ulcer, multiple myeloma, prostatic carcinoma, Down's syndrome and nephrotic syndrome. Clin Chim Acta 1974, 50: 43-51.

25. Stuart, J. \& Lewis, S.M. Monitoring the acute phase response (Editorial). Br Med J 1988, 297: 1143-1144. 